\title{
INDONESIAN CHINESE EDUCATION: PAST AND PRESENT
}

\author{
Leo Suryadinata
}

Students of the Indonesian Chinese usually recognize the existence of two Chinese communities: the peranakan (composed of Chinese already partly assimilated into Indonesian society) and totok (composed of Chinese still culturally Chinese). This essay attempts to examine briefly the historical development of education for both types of Indonesian Chinese in order to show: first, historical variations in their educational patterns; second, the conflict between them in terms of their educational aspirations and emphases; and third, the "totokization" of some peranakan Chinese children and the "peranakanization" of some totok children.

Education for the Chinese Before World War II

The Peranakan Chinese and Traditional Chinese Schools

Long before the arrival of the Dutch, the Chinese had come to Indonesia. Their numbers, however, were very small. Transportation difficulties and Imperial Decrees which established severe penalties for any Chinese leaving the Middle Kingdom discouraged any mass immigration to the Indies prior to the nineteenth century. ${ }^{1}$ The Chinese who did reach the Indies were predominantly Hokkien. Typically they did not bring their families with them but married native women, usually non- or nominally Muslim, and settled down. ${ }^{2}$ In the course of time, they formed a relatively stable, identifiable community which became known as the peranakan Chinese community. During the first half of the nineteenth century this community tended to become selfcontained; as the ratio of males and females within it grew more equal, inter-marriage with native women declined. ${ }^{3}$ Skinner has argued in

1. H. B. Morse, The International Relations of the Chinese Empire (London, New York: Longmans, Green \& Co., 1910), Vo1. I, p. 176; D. E. Willmott, The Chinese of Semarang: A Changing Minority Community in Indonesia (Ithaca: Cornel1 University Press, 1960), p. 24;G.W. Skinner, "The Chinese of Java," in Morton H. Fried, ed., Colloquium on Overseas Chinese (New York: International Secretariat, Institute of Pacific Relations, 1958), p. 2 .

2. Skinner, "The Chinese of Java," p. 2 .

3. The number of the Chinese in Java was 206,931 (110,002 males and 96,929 females) in 1880 ; and 242,111 (132,375 males and 109,735 females) in 1890. Nederlandsch Indië, Departement van Economische zaken, Volkstelling 1930 (Djakarta: 1935), vol. 7, p. 48. 
fact that at that time there was only one major Chinese community in Java, i.e., the peranakan Chinese community. New immigrants formed small transitory groups which were usually rapidly absorbed into the peranakan community. ${ }^{4}$

Peranakan Chinese were Indies-born and generally had indigenous blood from the female line. Most of them did not speak Chinese but communicated in the native languages. In the major towns of Java, especially along the north coast where most of the Chinese lived, a combination of Bazaar Malay and Hokkien terms (and 1ater Dutch as well) were used as the lingua franca. By the late nineteenth century this mixture had developed into Batavian Malay and had become the common language of the peranakan Chinese community throughout Java. Not surprisingly, peranakan publications were primarily in Batavian Malay. ${ }^{5}$

It is important to note that the Indies Chinese not only adopted local languages but also, to a considerable degree, the native way of life. Their customs, beliefs and religions were very mixed. A leading peranakan Chinese writer, Kwee Tek Hoay, noted quite accurately that from their China-born fathers the peranakan inherited practices from China, while through their mothers they were engulfed in native customs and traditions. 6 Another leading peranakan Chinese, Kwee Kek Beng, observed that peranakan Chinese were too Chinese to be Indonesian and too Indonesian to be Chinese. ${ }^{7}$

Not much has been written on the education of peranakan Chinese prior to the twentieth century. From the sketchy records available, it appears that early peranakan Chinese did not pay much attention to the education of their children, probably due to the

4. G. W. Skinner, "The Chinese Minority," in Ruth T. McVey, ed., Indonesia (New Haven: HRAF, 1963), p. 105.

5. Peranakan Chinese publications began to flourish toward the end of the nineteenth century. For a list of Chinese classics in Batavian Malay during that period see Tio Ie Soei, Lie Kimhok 1853-1912 (Bandung: L. D. "Good Luck," 1959?), pp. 112-114; for a special study on peranakan Chinese newspapers in the twentieth century, see Leo Suryadinata, The Pre-World War II Peranakan. Chinese Press of Java: A Preliminary Survey (Athens: Ohio University, Center for International Studies, 1971).

6. Kwee Tek Hoay, The Origins of the Modern Chinese Movement in Indonesia, trans. Lea E. Williams (I thaca: Cornell Modern Indonesia Project, Translation Series, 1969), pp. 10-11. Kwee Tek Hoay (1886-1951) was one of the most capable peranakan writers before World War II. He was a prominent journalist, educator and participant in the Chinese movement. For biographical data, see Leo Suryadinata, Prominent Indonesian Chinese in the Twentieth Century: A Preliminary Survey (Athens: Ohio University, Center for International Studies, 1972), pp. 13-14.

7. Kwee Kek Beng, Doea Poeloe Lima Tahon Sebagi Wartawan (Djakarta: Penerbit "Kuo-Batavia," 1948), p. 26. Kwee Kek Beng (1900was a leading peranakan journalist before World War II and editorin-chief of the important peranakan newspaper Sin Po in Djakarta. Suryadinata, Prominent Chinese, p. 13. 
fact that their fathers had come from a non-educated class and had been mostly interested in making money. Only a few wealthy Chinese hired Chinese tutors to teach their male children the Chinese language and classics. ${ }^{8}$ The first traditional Chinese school was established in Batavia in 1729 with some thirty students, but it was soon closed due to "mismanagement." 9 No other such school was recorded for this early period though this school was later revived.

Traditional Chinese schools began to increase, however, in the last quarter of the nineteenth century. In 1899 , for example, there were 217 such schools in Java (and Madura) with 4,452 students, and 152 schools in the Outer Islands with 2,170 students. ${ }^{10}$ The fact that almost all the twentieth century peranakan Chinese leaders born in the $1880^{\prime} \mathrm{s}$ had received a few years of traditional Chinese school education also indicates the new importance of such schools. ${ }^{1}$ Nevertheless, it is still not clear precisely why the traditional Chinese schools should have suddenly flourished in this period. ${ }^{12}$

Traditional Chinese schools were also known as Hokkien schools because their medium of instruction was Hokkien. Their curriculum was based on Confucian classics and emphasis was put on memorizing rather than understanding. The majority of students could not understand the meaning of the books they were taught to read. Moreover, even after studying in those schools for a few years they could still neither speak nor write simple Chinese. ${ }^{13}$ Probably the impracticality of these traditional schools was one reason why eventually many peranakan Chinese left them for Dutch and even Malay educational institutions when they had the opportunity.

The Peranakan Chinese and Dutch Education

Dutch schools, first established in 1816, were primarily for Dutch children. ${ }^{4}$ Peranakan Chinese children began to have access to Western

8. Kwee, Modern Chinese Movement, pp: 9-10. Also F. de Haan, Oud Batavia (Djakarta \& Leiden: Bataviaasch Genootschap van Kunsten en Wetenschappen en G. Kolff \& Co., 1922), vol. I, p. 506.

9. De Haan, Oud Batavia, vol. I, p. 506; Nio Joe Lan, Riwajat 40 Tahon Dari Tiong Hoa Hwe Koan-Batavia 1900-1939 (Djakarta: Tiong Hoa Hwe Koan, 1940), p. 21 .

10. M.F.A. Somers, "Peranakan Chinese Politics in Indonesia" (Ph.D. Thesis, Cornel1 University, 1965), p. 48.

11. Most of the peranakan Chinese leaders born during the $1880^{\prime} \mathrm{s}$ and $1890^{\prime}$ 's listed in Tan Hong Boen, Orang-Orang Tionghoa Terkemoeka di Java (Solo: "The Biographical Publishing Center," 1935?) indicated that they had received Hokkien education.

12. Probably it had something to do with the increase of 1 iterate Chinese immigrants to the Indies.

13. Lo T'ien, "Tung-yin-tu hua-ch'iao kuo-min chiao-yü kai-lun [A Note on Overseas Chinese Education in the East Indies]," in Sin Po Jubileum Nummer 1910-1935 (Djakarta: Sin Po, 1935), Chinese Section, p. 91. Also Nio, Riwajat, p. 24.

14. Tio, Lie Kimhok, p. 18. 
education only in the second half of the nineteenth century when three Dutch missionaries, C. Albers, S. Coolsma and D. J. van der Linden, began to set up less exclusive schools. Since these schools had difficulty in attracting Muslim children, the students came to be predominantly peranakan Chinese. ${ }^{15}$ In addition to Bible study, these schools taught Malay, writing, arithmetic, drawing and, in some advanced classes, Dutch. ${ }^{16}$ It was not, however, until the late nineteenth century that Chinese children, mainly the sons of Chinese Officers and very wealthy businessmen, were admitted to Dutch government schools. ${ }^{17}$ At the same time, some peranakan parents also sent their children to private Dutch schools run by retired Dutch officers and servicemen. 18

The colonial government was generally indifferent toward the education of Chinese children. At one time neither native Indonesians nor Chinese were permitted to enrol in Dutch government schools. A1though this ban was lifted in 1864, only very few peranakan and natives were admitted in practice. The Dutch government started specific educational facilities for the native Indonesians but neglected the Chinese until the beginning of the twentieth century. Many leading peranakan resented this indifferent attitude, and men like Phoa Keng Hek eventually started the Tiong Hoa Hwee Koan (The Chinese Association, hereafter THHK) schools in 1901 in order to force the Dutch authorities to open Dutch schools for peranakan children. 20

The Emergence of Modern Chinese Schools

The establishment of the THHK and its associated schools was the result of new developments in Asia in general, and in the Indies in

15. Tio Ie Soei mentions that prior to the $1880^{\prime} \mathrm{s}$ "there were not many Dutch who taught the Dutch language to Chinese children, [but] there were a few [Dutch] Christians who established schools where most of the students were Chinese. These missionaries were Albers, Coolsma and van der Linden." The total number of Chinese students involved is unknown, but Coolsma indicated that there were about 80-90 students enrolled at his school every year, of which the majority were Chinese. Ibid., pp. 19, 33-34.

16. Ibid., p. 18 .

17. Ibid., pp. 17-18; Kwee, Modern Chinese Movement, p. 14; Lea E. Williams, Overseas Chinese Nationalism: The Genesis of the PanChinese Movement in Indonesia 1900-1916 (Glencoe: The Free Press, 1960), pp. 27-28.

18. Tio, Lie Kimhok, p. 18 .

19. Liem Tjong Tiat, "Ethnicity and Modernization in Indonesia: A Comparative Study of Pre-Independence and Post-Independence Periods" (Ph.D. Thesis, University of Wisconsin, 1968), p. 74.

20. Tio, Lie Kimhok, p. 71. Phoa Keng Hek (1857-1937) was president of the THHK-Batavia frum 1900 to 1923 . 
particular. Toward the end of the nineteenth century, there was both an emergence of Western-educated peranakan Chinese leaders and a reinforcement of discriminatory policies against the Chinese by the colonial government. Indies chinese were confined to ghettoes and could only trave1 out of them if they had passes issued by the authorities. They were put under the jurisdiction of Native Courts which they regarded as inferior, and of Police Courts which they considered evil and arbitrary. ${ }^{21}$ Moreover, the Farming System (a system which used Chinese as revenue-collectors), which had long been the main source of income for the Chinese in Java, was abolished. ${ }^{22}$ At the same time, the Western-educated peranakan Chinese, while resentful of Dutch policies, were equally critical of prevailing customs in their own society, especially of wedding and funeral practices which they felt were superstitious and enormously expensive. ${ }^{2} 3$ Accordingly, they initiated a reform movement to improve both their cultural and their social condition in the Indies.

Meanwhile, Confucianism was being revived by the Chinese reformists in China. Peranakan Chinese in Java, inspired by this reformist example, used Confucianism as a support for their movement. It is not surprising that, at the beginning, the THHK, which was formed by peranakan leaders, aimed at promoting Confucianism and Chinese culture and established Chinese-medium schools to serve this purpose. As time passed, the THHK increasingly became an educational institution, concerning itself overwhelmingly with the foundation of Chinese-medium schools, initially in Java, later in the whole of the Indies.

Unlike traditional Chinese schools, the first THHK school was modeled after the overseas Chinese school in Japan. The first principal of the THHK school in Batavia, Lu Kui-fang, was a Hokkien who introduced the primary school system used in Japan and got his teachers from the same source. ${ }^{24}$ Confucian classics were abandoned and simple Chinese textbooks were introduced. The teaching materials were taken from Japanese textbooks and the medium of instruction was no longer Hokkien but Tjeng Im (Cheng-yin), later known as Kuo-yü or the National Language. ${ }^{25}$ Only when the Shanghai Commercia] Book Store began to print Chinese textbooks did the THHK school abandon its Japanese materials.26 It is interesting to note that English, not Dutch, was taught as the first foreign language. ${ }^{27}$ As a matter of fact, English

21. Williams, Overseas Chinese Nationalism, pp. 27-36.

22. Lea E. Williams, "The Ethical Program and the Chinese of Indonesia," Journal of Southeast Asian History, II (1961), pp. 35-42.

23. Kwee, Modern Chinese Movement, p. 13.

24. Lo, "Kuo-min chiao-yü," pp. 87-88; Li Ch'uan-shou, "Yin-tu-ni-hsiya hua-ch'iao chiao-yl shih [A History of Overseas Chinese Education in Indonesia]," in Nan-yang hslleh-pao [Singapore], vol. 5, part I (July 1959), p. 2 .

25. Nio, Riwajat, p. 16 .

26. Lo, "Kuo-min chiao-yu," pp. 87-88; Li, "Chiao-yü shih," p. 2.

27. One of the main reasons for this was that English had a wider use than Dutch. Lo, "Kuo-min chiao-yü," pp. 88-89. Kwee Tek Hoay argued that the teaching of English revealed the Indies Chinese 
was so emphasized in the THHK school in Batavia that an English section was established. ${ }^{2} 8$

The THHK school was financed and managed by the local Chinese community and proved to be very popular. In 1901, there was only one THHK school, but two years later the number had increased to thirteen, and by 1908 , there were fifty-four. ${ }^{29}$ This continued growth attracted the close attention of both the Chinese and the Dutch colonial governments.

The Establishment of Dutch Schools

for Chinese Children

The Chinese Imperial Government, realizing the importance of the Overseas Chinese for political and financial support, now increased its contact with the Indies Chinese. Chinese officials were sent to the Indies to supervise Chinese schools, and scholarships were given to Chinese children to study in China. A few THHK graduates took the scholarships and went to their ancestral 1 and. ${ }^{30}$

The development of the THHK schools and the increasing interest of the Chinese Imperial Government in the Indies Chinese caused the Dutch authorities to fear losing control over the peranakan. As early as 1905, the Council of the Indies was of the opinion that schools for the Chinese should be run along Dutch lines. ${ }^{31}$ By 1907 , the Minister of Colonies, D. Fock, had come to consider the question of schools for the Chinese as urgent. ${ }^{32}$ In the same year the Council of the Indies advised the founding of a special school for the Chinese. One year later, the first Dutch primary school for the Chinese, the Hollandsch-Chineesch School (HCS), was established in Batavia, to be duplicated later in other major cities. ${ }^{3}$

These schools were modeled after the government schools for Europeans (Europeesche Lagere Scholen, ELS), using Dutch as the

resentment of the colonial government. K.T.H. "Onderwijs Hoakiauw di Indonesia, I," Panorama, August 7, 1931.

28. The English section was known as the "Yale Institute" because it was headed by a Yale graduate. The section was merged with the Chinese section in 1905. Suryadinata, Prominent Chinese, p. 15; Yang Sse-hsiang, "Yeh-ch'eng chung-hua hui-kuan shih-lüeh [A short history of the Tiong Hoa Hwe Koan Djakarta]," in Hari Ulang Ke-50 Tiong Hoa Hwee Koan Djakarta (Djakarta: Tiong Hoa Hwe Koan, 1950), p. 60 .

29. Lo, "Kuo-min chiao-yu," p. 89.

30. Nio, Riwajat, p. 101.

31. S. L. van der Wal, Het Onderwijsbeleid in Nederlands-Indië 19001940: Een Bronnenpublikatie (Groningen: Wolters, 1963), p. xxiii; also pp. 41-42.

32. Ibid., p. xxiv; also p. 99.

33. Ibid., p. xxiv; a1so pp. 99-104. 
medium of instruction, and teaching neither Chinese nor Chines culture. In 1910, the Dutch government promulgated the Dutch Nationality Law by which peranakan Chinese were considered to be Dutch subjects. A few years later, the Dutch government opened the ELS to the Chinese and the HCS was linked to Dutch Secondary Schools (Hogere Burgerscholen, HBS). ${ }^{34}$ Obviously these were meant to counter-balance the Chinese nationalist movement in general and the THHK schools in particular. ${ }^{35}$

Primarily due to their rather peculiar cultural background and their utilitarian attitude toward education, peranakan Chinese were more attracted to Dutch schools, whose numbers therefore increased rapidly at the expense of the THHK schools. One contemporary Dutch newspaper indeed observed that: "The government's measure of setting up Dutch schools for the Chinese seems to be very effective; within the next few years the THHK schools will disappear." ${ }^{36}$

The prediction proved incorrect--the THHK did not disappear. But it was true that the number of Chinese students receiving Dutch education continued steadily to increase. Already in 1915, 8,060 Chinese children were in Dutch schools while 16,499 attended THHK schools. Apparently the entrance requirements for Dutch schools were harder than those for THHK schools and only those who belonged to the middle class could afford to pay the higher school fees charged by the Dutch schools. According to a leader of the Djawa Hak Boe Tjong Hwee (General Educational Association of Java), most peranakan Chinese students who went to the THHK schools were those who had failed to enter Dutchmedium schools. ${ }^{37}$

34. Ibid., p. xxvii; a1so pp. 258-265.

35. The numbers of Chinese students in Chinese-medium and Dutch-medium schools from 1915-1926 were as follows:

\begin{tabular}{ccc}
$\frac{\text { Year }}{1915}$ & Chinese-medium $^{\mathrm{a}}$ & Dutch-medium $^{\mathrm{b}}$ \\
1920 & 16,499 & 8,060 \\
1925 & 14,242 & 13,617 \\
1926 & 29,401 & 19,382 \\
\hline
\end{tabular}

a. Based on Hsü K'o-ch'eng, "San-shih-nien ho-shu huach'iao chiao-yü shu-lueh [A Survey of Dutch Indies Chinese Education in the Last Thirty Years], "in Tsuichin san-shih-nien chung-kuo yü nan-yang shiao-wen-k (Changhai: Chung-hua shu-chu, 1928), p. 8 .

b. Based on figures cited in Wa1, Onderwijsbeleid, pp. 693699; Paul van der Veur, Education and Social Change in Colonial Indonesia (I) (Athens: Ohio University, Center for International Studies, 1969), p. 11 .

c. Based on Hsü k'o-ch'eng's figures, including 3,601 children in kindergarten. Wal's figures do not include children in kindergarten.

36. Lo, "Kuo-min chiao-yü," p. 91.

37. "Conferentie Hak Boe Tjong Hwee Surabaja," Sin Po., January 8 , 1919 . 
Though larger in numbers, the THHK schools soon showed that they could not meet the demands of peranakan Chinese. Their curriculum was suitable for life in China, ${ }^{38}$ but it did not suit peranakan Chinese living in the Indies. The employment prospects of THHK graduates were seriously limited by the fact that the Chinese language was not used in government service. This made the THHK schools relatively unattractive to we11-to-do peranakan Chinese, who had come to favor and aspire to white-collar and professional employment. In addition, THHK school graduates were subject to social discrimination. and were paid less than Dutch-educated Chinese at the same level. Moreover, twenty years after their first establishment in 1901 , the THHK schools were still primary schools. ${ }^{39}$ It was also widely believed that people in charge of the THHK schools did not know much about education; and indeed mismanagement occurred at almost al1 THHK schools. 40 Not surprisingly, many peranakan THHK leaders sent their children to the HCS instead of the THHK Schools, 4 and in the twenties particularly many peranakan Chinese transferred their children from THHK to Dutch schools.

In the meantime, scarcely noticed, a stable totok Chinese community was emerging, owing to the constant influx of Chinese immigrants (both male and female). ${ }^{42}$ These China-born Chinese were culturally Chinese and naturally strongly China-oriented. But, more important, their children, though born in the Indies, did not become peranakan; rather, they shared their parents' culture and hence were classified as totok Chinese. (As 1ate as 1930, however, the Chinese in Java were still overwhelmingly peranakan.) ${ }^{43}$

Peranakan Chinese Attempts to Reform the THHK Schools

Some THHK school leaders were fully aware of the problems confronted by the THHK schools. They attempted to improve the schools through a centralized organization called Djawa Hak Boe Tjong Hwee

38. Thyrsis, "Tiong Hoa Hwe Kwan atawa Pendidikan Bangsa Tionghoa di Hindia," Sin Po, November 3-4, 1916; K. T. H., "Onderwijs Hoakiauw di Indonesia, V," Panorama, September 5, 1931.

39. Both Nio Joe Lan and Lo T'ien wrote that the THHK-Batavia established a secondary school division in 1913 but it was closed down six months later due to lack of funds and students. Nio, Riwajat, p. 110; Lo, "Kuo-min chiao-yt," p. 91. Lo T'ien also wrote (in 1935) that Chinese secondary schools were only "established in the last ten years." (Ibid.)

40. Thyrsis, "Tiong Hoa Hwe Kwan"; Hwee Hing Tjiat, Doea Kapala Batoe (Berlin: privately published, 1921), pp. 104-113.

41. Kwee, Doea Kapala Batoe, pp. 112-113; Sin Tit Po, February 1 , 1936 .

42. Skinner, "The Chinese Minority," p. 105.

43. According to the 1930 Census, 63.5 per cent of the total Chinese population in Java were third generation, i.e., fully peranakan. Skinner, "The Chinese of Java," p. 3 . 
(General Educational Association of Java). The main function of this association was to supervise the operation of the THHK schools and to recruit qualified teachers from China. ${ }^{44}$ A special section in the association called Kauw Yok Hwee (Educational Society) was established prior to 1919 to review the THHK school curriculum. When the Djawa Hak Boe Tjong Hwee held its annual conference in 1919 the Kauw Yok Hwee suggested that the curriculum should be adapted to Indonesian conditions since most peranakan Chinese continued to live in Indonesia after receiving their THHK school education. But though new textbooks were in fact planned, they were never published." 5 One of the main reasons was that both the Hak Boe Tjong Hwee and the THHK schools were short of operating funds and many people were only concerned with maintaining the status quo.

Understandably, the THHK schools continued to decline in terms of peranakan support and more and more peranakan Chinese sent their children to Dutch schools. More and more Dutch private schools came into being to meet the increasing demand. ${ }^{46}$ As a result, in the midtwenties, a few peranakan leaders even advocated the conversion of THHK schools into HCS-type schools. The most prominent advocates of this idea were Kwee Hing Tjiat and The Kian Sing.

In 1925, Kwee Hing Tjiat, a peranakan who was expelled to China by the Dutch government, became thoroughly disillusioned with the THHK schools and urged the Indies Chinese to "bury" them. He offered no substitute, but indicated implicitly that Dutch school education was more suitable for the Indies Chinese. Many peranakan newspapers joined him in attacking the THHK schools. ${ }^{4}$ This trend gave rise to the establishment of the Tiong Hoa Kauw Yok Gian Kioe Hwee (Chinese

44. K.T.H., "Onderwijs Hoakiauw di Indonesia, IV," Panorama, August $27,1931$.

45. Ibid.

46. The growth of HCS in the Netherlands Indies from 1915-1928 is dicated by the following figures:

\begin{tabular}{lcc} 
& \multicolumn{2}{c}{ Number of Schools } \\
\cline { 2 - 3 } Year & $\frac{\text { Pub1ic }}{27}$ & $\frac{\text { Private }}{1915}$ \\
1918 & 33 & 2 \\
1920 & 34 & 14 \\
1922 & 34 & 17 \\
1924 & 38 & 23 \\
1926 & 45 & 36 \\
1928 & 53 & 51 \\
\hline
\end{tabular}

Source: Somers, "Peranakan Chinese Politics," p. 51.

Dr. Somers noted that "the mushroom growth of the private HCS was largely from the activity of the Christian missionaries in the field." (Ibid., p. 52.) See also above, footnote 35, for the total number of Chinese students in Dutch-medium schools (HCS and others).

47. "Soeara Pers Tentang Voorstel Toean The Kian Sing," Panorama, Apri1 3, 1927; Kwee Tek Hoay, "Conferentie Tentang Onderwijs Tionghoa," Hoa Kiao (Surabaja), December 1925, pp. 4-5. 
Educational Research Association) which held a conference to discuss Chinese educational problems so that a system could be introduced which would end conflict and division in the education of Indies Chinese. The conference decided to build a model school for all Chinese in the colony. However, the plan could not be carried out due to a lack of interest and funds. ${ }^{4}$

Kwee Tek Hoay analysed the difficulties of instituting a mode 1 plan or school in view of the various conflicting interest groups within the Indies Chinese community. ${ }^{49}$ He pointed out that there were at least five major interest groups concerned: (1) We11-to-do and middle class peranakan who wanted to continue to live in the Indies and were interested in higher education; (2) Poor peranakan who wanted to continue to live in Indonesia and were satisfied provided their children knew how to read and write Romanized Malay; ${ }^{50}$

(3) Peranakan Chinese nationalists who wanted to send their children to China to help the country and believed that Chinese education was indispensible even if their children did not go to China; (4) Peranakan and totok utilitarian nationalists who wished to preserve their Chinese identity but believed that the Chinese language was not sufficient for making a good living; and (5) Totok Chinese, especially Hakka and Cantonese, who wanted to return to China.

These groups, Kwee Tek Hoay argued, obviously desired different types of education for their children. To give one type of education to all was simply unrealistic and was bound to fail.

A second attempt to reform the THHK schools was made in 1927 by The Kian Sing, a former peranakan Chinese nationalist, in Surabaja. He proposed that they be converted into new schools with Dutch education as the basis of the curriculum so that students could continue their education in the Netherlands or in government schools in the Indies. As for the Chinese language, it would be given in evening classes; special teachers would be in charge of these classes which would include a course on Chinese culture. ${ }^{31}$ The Kian Sing sent his

48. K.H.T., "Onderwijs Hoakiauw di Indonesia, VI," Panorama, September $10,1931$.

49. Ibid.; also Kwee, "Conferentie Tentang Onderwijs Tionghoa," pp. 6-7.

50. In 1928 the Dutch began to establish Maleisch Chineesche Scholen (MCS, Ma1ay Chinese Schools) to accommodate poor peranakan Chinese. This was a six-year elementary school and used Malay as the medium of instruction. Dutch was only taught as a subject. Some peranakan Chinese leaders were against the establishment of such schools because they claimed that the standards were low. However, the MCS continued to grow over the next ten years. Koo Liong Ing, "Sekolah Rajat Tionghoa (Prae-advies boeat Chung-hua Congress II)," The National (Fort de Kock), 2 (April 1928), pp. 13-17; Raden Loekman Djajadiningrat, From Literacy to University (The Netherlands and Netherlands Indies Council of the Institute of Pacific Relations, Bulletin No. 3, Mont Tremblant, 1942), p. 34. Gedenkboek 2e Lustrum CHH 1928-1938 (Djakarta: Chung Hwa Hui, 1938), pp. 61, 71.

51. "Plan Perobahan Tiong Hoa Hwe Koan dari Toean The Kian Sing," Panorama, March 27, 1927. 
proposal to the THHK-Batavia for approval, and planned to call a public meeting in Surabaja to discuss it.

Immediately after the announcement of the proposal, Kwee Tek Hoay wrote in Panorama:

There is no doubt that some Chinese in Indonesia will profit from The Kian Sing Plan, i.e. the people who are going to stay here forever. But the plan is also to be carried out by all hak-tong (Chinese schools) in Java; this is impossible. Mr. The Kian Sing seems to have forgotten that the Chinese in Indonesia are not comprised of peranakan alone. I think that half of them are either totok or people whose way of 1 ife and ideas are similar to those of totok. They still have close ties with China and make round-trips to China. For this group, the Chinese language is extremely important. Even if this group wanted to learn a foreign language, they would take English [instead of Dutch] because English is used by the intellectuals In East Asia while Dutch is only used in the Dutch territories. Therefore, to ask children of this group to learn Dutch [as a first language] and Chinese as a secondary language is unrealistic and will cause the failure of the plan. 52

Kwee remarked that since The's plan would benefit peranakan Chinese he should carry it out without waiting for agreement from all THHK leaders, of whom many were totok. Kwee warned The that if he waited for approval from the THHK leaders, he would not be able to implement his plan.

Kwee's analysis was convincing and his prediction was also correct. The THHK schools in Batavia and elsewhere disapproved of the reform plan; THHK school teachers in Surabaja and other places were even mobilized for a meeting to oppose it. This was very understandable since conversion of all THHK schools would have meant their total reorganization, the dismissal of the majority of THHK school teachers and the "peranakanization" of totok children. Not surprisingly, China-oriented totok and THHK school teachers gathered for the meeting, attacking The Kian Sing and strongly rejecting his plan. ${ }^{53}$

Peranakan vs. Totok in Education

Nevertheless, peranakan Chinese quietly established more and more Dutch private schools. For instance, a "National" HCS (Dutchmedium school with a subject in the Chinese language and culture) was founded in Surabaja by a group of Dutch-educated peranakan. ${ }^{4}$

52. [Kwee Tek Hoay], "Dari Toean The Kian Sing," Panorama, March 27 , 1927.

53. [Kwee Tek Hoay], "Kian Sing Soehoe, Antjhoa?," Panorama, Apri1 16, 1927.

54. Ibid. 
Dr. Yap Hong Tjoen, a prominent physician in Jogjakarta, also founded a Dutch private school in that town. A similar school was established in Bogor by a group of local peranakan Chinese. ${ }^{5}$

In 1927 , at a large gathering in Semarang where most of the peranakan intellectuals were present, the Dutch government was urged to open more HCS and to add the Chinese language and culture as a subject. The government did establish a few more HCS but it never reformed the HCS curriculum. Probably it feared that the addition of Chinese language and culture would lead to an undesirable stimulation of Chinese nationalist feelings.

According to a contemporary survey, in 1926 there were 27,802 Chinese children receiving Dutch education while 32,668 were in Chinese-medium schools (THHK schools and other Chinese-medium schools sponsored by speech group organizations). ${ }^{56}$ But after the midtwenties the role of peranakan and the THHK schools in CHinese education began to decline. Totok Chinese established their own schools because they were not satisfied with the education given in the THHK schools. In Bandung, there were three Chinese-medium schools run by totok groups. In Batavia, Hakka, Hokkien and Cantonese founded their own schools, perhaps because the THHK schools were meant for all Chinese regardless of their group origins. ${ }^{7}$ Totok Chinese gradually took over the leadership of Chinese education in the Indies. In 1927 , Kwee Tek Hoay wrote:

In small places where the totok are not able to sponsor their own schools, they have now taken over the THHK schools from the hands of the peranakan. The THHK schools in Pasar Baru, Tanah Abang, Pasar Senen [places in Djakarta] and others are now in the hands of the totok, while the students [in these THHK schools] are either totok children or two kinds of peranakan children: those who are poor and those who did not get seats in the HCS. The THHK school in Bogor, which used to be 90 per cent in the hands of the peranakan, is now beginning to be taken over by the totok, because the totok have an interest in the schools where the Chinese language is taught. We believe that gradually in all places where there are many totok, the Chinese-medium schools will be run by them, while those run by the peranakan will either be closed or half-dead due to 1 ack of attention. ${ }^{58}$

In 1932, a leading Kuomintang newspaper in Djakarta, T'ien-sheng jih-pao conducted a survey of Chinese-medium schools in Indonesia. It showed that many of these schools did not bear the name of the THHK. For instance, in Djakarta there were fifteen Chinese-medium schools, of which thirteen were under different names. ${ }^{59}$ These schools were

55. Ibid.

56. See the table in footnote 35. Speech group organizations were established by totok Chinese based on the dialect they spoke (i.e., Hokkien, Hakka, Cantonese, etc.).

57. [Kwee Tek Hoay], "Dari Toean The Kian Sing."

58. Ibid.

59. Ho-shu ko-fou t'ung-ch'iao hstleh-hsiao tiao-ch'a-piao [A Survey 
run by totok organizations: for example, the Kwong Djin (Kuang-jen) School was run by a Cantonese association (Kuang-shao hui-kuan); the Gie Seng (I-Ch'eng) School was sponsored by a Hakka association (Hua-ch'iao shu-pao-she), the Pin Min ( $P^{\prime}$ ing-min) School was established by another Hakka organization, and a Hokkien school was founded by the Fu-chien hui-kuan. ${ }^{60}$

The rapid increase of totok-sponsored Chinese-medium schools was due partly to the rapid growth of the totok population and partly to Kuomintang policy. After their success in unifying China, the Kuomintang worked to establish closer ties with the overseas Chinese. An Overseas Chinese Affairs Bureau was established and an educational policy for the overseas Chinese was also laid down. ${ }^{61}$ Chinese-medium schools were encouraged and were to be supervised by Chinese consuls on behalf of the Chinese government to assure that their operation was in the Chinese national interest. It is interesting to note that the Chinese government prohibited Chinese-medium schools overseas from accepting grants from local governments; financial support had to come from the Chinese community itself.62 Many Chinese schools, however, violated this regulation in the forties, indicating that the Kuomintang government had 1ittle success in implementing this part of its policy.

As a general rule, totok Chinese came to send their children to Chinese-medium schools while peranakan Chinese tried to send theirs to Dutch schools. (The $\tilde{T}$ 'ien-sheng jih-pao survey showed a huge majority of the students in Chinese-medium schools to be peranakan. ${ }^{6}$ I believe that this judgment was mistaken or rather that what $T$ 'iensheng jih-pao meant by peranakan were Indonesia-born Chinese children even if they were culturally totok.)

Sin Po (Hsin-pao), the largest Chinese language newspaper in the Indies, conducted a survey on Chinese education in 1934 and came to the following conclusions: ${ }^{64}$ There were 450 Chinese-medium schools in the Indies, of which only twenty had a secondary school section. There were 117 Dutch-medium primary schools for Chinese, but no special secondary schools, since the Dutch authorities had introduced one secondary school for all races in the Indies. There were about 45,000 Chinese children receiving Chinese education, ${ }^{65}$ of which 1,251

of Chinese Schools in the Dutch East Indies],

(Djakarta: T'ien-sheng jih-pao, 1932), pp. X1-X3.

60. Ibid.

61. Chung-hua min-kuo fa-kui ta-ch'lien [Regulations and Laws of the Republic of China] (Shanghai: The Commercial Book Store, 1937), pp. 314, 1290-1294.

62. Ibid.

63. The survey covered ninety-three schools in the Indies, of which seventy-seven had 70-100 per cent peranakan students. See Hoshu, pp. X1-X19.

64. Lo, "Kuo-min chiao-yu," pp. 91-92.

65. Only 259 schools (out of 450) responded to Sin Po's questionnaire. There were 30,438 students in these schools $\overline{15,200}$ was in Po's estimate of enrolment in the 191 schools which did not respond. 
were secondary school students. A further 23,353 Chinese were receiving a Dutch education, of which 1,651 were secondary school students.

However, in 1936 , Dr. Loe Ping Kian, a peranakan physician who was interested in the education of Indies Chinese, made a special study of Chinese children in the Indies and their education. He revealed that $\operatorname{Sin} P_{0}$ had underestimated the number of Chinese students receiving a non-Chinese education. While accepting $S$ in $P_{0}$ 's figures on Chinese-medium school students, he gave the figure of Dutch-educated and Malay-educated Chinese students (based on government statistics and his own research) as 53,000.66 Probably Dr. Loe's figure was somewhat high, but one can certainly argue that Chinese students in non-Chinese medium schools were at least as numerous as those in Chinese-medium schools.

\section{Advanced Education for the Indies Chinese}

There was no advanced or tertiary education for Chinese-medium school graduates in pre-war Indonesia. Those who wanted to further their studies had to go to China, unless they knew sufficient English to attend universities in Hong Kong or Western countries. 67

No figures are available regarding Chinese-medium school graduates in China. Sin Po claimed that in the thirties about 800 Chinese students went there from the Indies every year. ${ }^{8}$ It is not clear whether they were peranakan or totok, but Amry Vandenbosch notes that only 300 Indo-Chinese (peranakan) students were called back from Shanghai at the start of the Sino-Japanese conflict. ${ }^{9}$ One can be reasonably sure that the numbers of peranakan going to China for further studies would not have been large, since employment opportunities were limited. Most of the peranakan students who went to China eventually

66. These included 24,000 in public (government) and subsidized Dutchlanguage schools, 2,500 at Dutch schools for Europeans, 13,000 at Vernacular and Malay schools, and 13,500 at non-subsidized and oth other "wild" schools. The study was first released to the Fourth Congress of the Hua Chiao Tsing Nien Hui (Overseas Chinese Youth Association). The full text was published in Sin Tit Po, Apri1 17-22, 1936; and in Sin Po Wekelijsch Editie, Apri1 25-June 13, 1936. Part of the study is cited in R. Diffelen, "Het Onderwijs voor Chineezen," Koloniale Studien, 20 (1936), pp. $42 \mathrm{ff}$.

67. Some THHK graduates took the Cambridge High School Certificate in Hong Kong, others went to Shanghai to attend universities such as Saint John and then transferred to universities in the United States. A number of them came back to the THHK-Batavia to teach after they received advanced degrees overseas. Nio, Riwajat, pp. $324-325$.

68. Lo, "Kuo-min chiao-yü," p. 92.

69. Amry Vandenbosch, The Dutch East Indies (Berkeley: University of California Press, 1944), p. 205 . 
returned to Java and devoted themselves to Chinese education. ${ }^{70}$ (These Chinese college graduates often became ardent supporters of Chinese nationalism.)

Unlike the graduates of Chinese schools, who had to go abroad to continue their studies, graduates of Dutch-medium schools could enter local universities and colleges. In 1928 there were already fortythree Chinese students at Indies colleges. ${ }^{71}$ Local institutions, however, could not accommodate very many students, and so many Chinese went to the Netherlands. By 1940 there were 741 peranakan Chinese students in universities in the Netherlands, of whom 107 obtained their degrees. ${ }^{72}$ (These graduates eventualiy returned to the Indies and, as a general rule, they were oriented to the Indies rather than to China.)

\section{Education for the Chinese After World War II}

The Development of Chinese-Medium Schools

During the Japanese occupation (1942-1945), Dutch and other Western schools were banned, and only Indonesian and Chinese-medium schools were permitted to operate, starting from August 1, 1942. The Japanese authorities treated totok and peranakan "with impartial disdain and forced their organizations into a single mold." 73 "The peranakan were also encouraged to study Chinese. ${ }^{74}$ Chinese children who attended the HCS before the war were now receiving their education in Chinese-medium schools. There are no figures available for the number of students involved, but, given the social conditions in that period, it is likely that more Chinese were in Chinese schools than in Indonesian schools. This resulted in a "totokization" (or resinification) of many peranakan Chinese, since they were now heavily exposed to Chinese language and culture.

Another remarkable increase in Chinese schools took place after Indonesia proclaimed her independence in 1945. Prior to December 1949, Indonesia was still divided into Federal (Dutch-controlled) and Republican areas. The Dutch apparently encouraged the establishment of Chinese-medium schools. This change in Dutch policy toward Chinese education was certainly motivated by the hope of winning the support of the Chinese for a restoration of Dutch power in Indonesia.

70. K.T.H., "Onderwijs Tionghoa di Indonesia, II," Panorama, August 13,1931 .

71. Hollandsch-Inlandsch Onderwijs-Commissie, Publicatie, No. 1. (Buitenzorg, 1920), Part II, Tables XLI, XLII and XIIII.

72. Wa1, Onderwijsbeleid, p. 700 .

73. G. William Skinner, "Java's Chinese Minority: Continuity and Change," Journal of Asian Studies, XX, 3 (May 1961), p. 360.

74. Li, "Hua-chi'iao chiao-yu shih," Part I, pp. 6-7. 
In October 1947 , a regulation was introduced that Chinese-medium schools would be subsidized, but that schools receiving grants from the Dutch Indies government should teach Indonesian six hours a week, starting from the third year of primary school. ${ }^{75}$ The Ministry of Education also granted teaching certificates to Chinese-medium school teachers, and allowed Chinese to be taught in government or subsidized schools where the majority of students were ethnic Chinese. ${ }^{76}$

The number of Chinese-medium school students in the Federal area was larger than in the Republican area. In 1949 there were 816 Chinese schools in the former, of which forty-three were secondary schools and 319 subsidized by the Federal government. ${ }^{77}$ One hundred sixty-five thousand three hundred fifteen students were enrolled in Chinese primary schools and 10,292 in secondary schools. In the Republican area, the number of Chinese schools was estimated at ninetytwo and enrolment at about 55,000.78 (It should be noted that Dutchmedium schools reopened after the Japanese surrender and were attended by many peranakan Chinese. Peranakan Chinese in 1948 formed the largest group (67.9 per cent) of students at the University of Indonesia (Djakarta), which was a Dutch-medium university. ${ }^{79}$ )

With the transfer of sovereignty to the Indonesians in December 1949 , the whole territory of the Dutch East Indies, except for West Irian, came under the control of the Indonesian government. Dutch schools were closed and peranakan Chinese who were in Dutch schools continued their education in Indonesian-medium schools run either by private groups or by the government. In 1950, there were 50,000 Chinese students in Indonesian schools. ${ }^{80}$ Nevertheless, Chinesemedium school students were larger in number: in that same year, around 250,000 Chinese students were enrolled in Chinese-medium schools, and of this number about 150,000 were Indonesian citizens. ${ }^{81}$

The remarkable increase of Chinese-medium school students soon after Indonesia's independence can be explained in terms of various factors. Apart from the closing of Dutch schools and the limited number of Indonesian schools--which would not cope with the growing number of Chinese children after the war-there was a lack of confidence among the Chinese in the newly opened Indonesian schools. In addition, the emergence of the People's Republic of China gave rise to strong Chinese nationalist feelings.

75. Li, "Hua-ch'iao chiao-yü shih," Nan-yang hsueh-pao, vo1. 15, part II (December 1959), p. 42 .

76. Ibid.

77. Li, "Hua-ch'iao chiao-yul shih," Part I, pp. 10-11.

78. Ibid.

79. Ibid., pp. 7-8.

80. M. Hutasoit, Compulsory Education in Indonesia (Paris: UNESCO, 1954), p. 54 , cited in Liem, "Ethnicity and Modernization in Indonesia," pp. 208-209.

81. Ibid. 
In 1950, the Indonesian government stopped subsidizing Chinesemedium schools, ${ }^{82}$ but Indonesian citizens of Chinese descent were still allowed to attend them. In 1952, the government began to exercise some control over these schools. All Chinese-medium schools had to be registered with the Ministry of Education and the Indonesian language had to be taught from the third year at the primary school level for at least four hours a week. ${ }^{3}$ Apart from this, however, there was no actual control over Chinese-medium school textbooks, teachers or students. During 1952-1953,1,371 Chinese schools with 254,730 students were registered with the Ministry of Education. ${ }^{84}$

The Struggle Between Pro-Peking and Pro-Taipei Schools

As stated earlier, the political struggle in China had repercussions in Chinese-medium schools in Indonesia. Pro-Taipei leaders wanted to keep Peking's influence out of the schools. Many well-established schools were in the hands of the pro-Kuomintang group who insisted on orienting the schools toward Taipei rather than Peking. Many pro-Peking teachers were dismissed. In Bandung, for instance, the Ch'ing-hua school dismissed twenty-four pro-Peking teachers, who responded by establishing (in 1951) a New Ch'ing-hua school to confront the old one. ${ }^{85}$ The influence of Peking grew, however, and many schools eventually fell into the hands of pro-Peking groups. This was probably due to the fact that most Chinese teachers were young, China-born and pro-Peking. ${ }^{86}$ The fact that Indonesia recognized the Peking government also contributed to the growing influence of the pro-Peking group. Nonetheless, it would be wrong to say that, prior to 1957 , the overwhelming majority of Chinese schools were proPeking. In 1957, there were 1,600 Chinese schools, of which 700 were pro-Taipei, fifty-six were run by churches, and the rest were mostly pro-Peking. 87

It may be useful here to confine our analysis to Chinese-medium schools in Djakarta, in order to get a clearer picture of Chinese education in Indonesia prior to 1958. Of the forty-five schools then

82. Li, "Hua-ch'iao chiao-yü shih," Part II, p. 43.

83. For the text of the 1952 regulation, see Departemen Pendidikan, Pengadjaran dan Kebudajaan, Pengawasan Pengadjaran Asing

(Djakarta: DPP\&K, n.d.), pp. 50-56.

84. Ibid., p. 14 .

85. Li, "Hua-ch'iao chiao-yü shih," Part I, pp. 8-9.

86. G. W. Skinner, Report on the Chinese in Southeast Asia (Ithaca: Corne11 University, Southeast Asia Program Data Paper, 1950), p. 66 .

87. T'ai-pei hua-ch'iao chih pien-wei-hui [Taipei Overseas Chinese Annals Compilation Committee], Hua-ch'iao chih: yin-ni [Overseas Chinese Anna1s: Indonesia], (Taipei: n.p., 1961), pp. 102, 104. 
operated in Djakarta, about twenty were pro-Taipei, while the rest were mostly pro-Peking. ${ }^{8}$ The largest pro-Peking secondary schools were the $\mathrm{Pa}-\mathrm{ch}$ 'eng chung-hsueh ( $\mathrm{Pa}$-chung) and the Chung-hua chunghsueh (Hua-chung). The Pa-chung was established in 1945, as a joint effort of three pre-existing schools, the Kuang-jen school, the Fu-chien school and the Hua-ch'iao school. Initially it was not leftist in orientation and had only 700 students. But in the fifties it began to be controlled by pro-Peking Chinese. By 1955 the number of students at the $\mathrm{Pa}$-chung school had increased to 3,300. As for the number of teachers, there were twenty in the initial period but this had grown to 100 by $1955 .^{89}$ (It should be noted that the THHK school, which was the oldest Chinese school in Djakarta, was able to remain neutral for a number of years. This school was peculiar in that "it starts instruction in Chinese and introduces more and more English until all appropriate courses are taught in English during the final year." 90 The students were primarily the offspring of peranakan and a significant number of teachers were Java- and Straitsborn Chinese. 91 The school, however, fell into the hands of a proPeking group towards the end of the fifties. ${ }^{92}$ )

Among the pro-Taipei secondary schools, the Chung-san chunghsueh (Chung-san) and the Yin-ni kao-chi shang-yeh hsueh-hsiao (Kaoshang) were the largest. Unlike the Pa-chung and the Hua-chung, these schools were comparatively new. In 1956, the Chung-san had 1,500 students and forty-five teachers, while the Kao-shang had 950 students and twenty teachers. ${ }^{93}$

These two types of Chinese-medium schools existed side by side during the period of 1950-1957. The teachers were mostly from mainland China; a smal1 percentage were Indies-born but with an education in Chinese normal schools or universities in China. ProPeking school teachers were usually younger and were proud of Chinese Communist achievements, while pro-Taipei teachers were older and associated with the Kuomintang. Many totok Chinese who were noncommunist sent their children to pro-Peking schools because they thought that these schools provided their children with a better education. 94

88. Ibid., p. 104 .

89. For information on the Pa-chung school, see Ch'un-han, "T'an-t'an shih-nien lai te yeh-hua chiao-yu [Chinese Education in Djakarta in the Last Ten Years]," in Sheng-huo pao shih-chou nien chinien-k'an (Djakarta: Sheng-huo pao, 1955), p. 81 .

90. Skinner, Report, p. 66 .

91. Ibid.

92. Like other Chinese-medium schools, after 1958 the THHK was divided in two: there was an Indonesian section (for Indonesian citizens) and a Chinese section (for aliens). The Chinese section was under pro-communist control. Sung Chung-ch'uan, the president of a pro-communist organization in Djakarta, was the principal (1960-1962).

93. Hua-ch'iao chih, p. 104 .

94. Typically, pro-Peking schools used textbooks published on the mainland or by leftist Hong Kong publishing companies, while 
Where did the Indonesian Chinese go, prior to 1958, once they had finished Chinese secondary school education? No statistics are available, but from my own personal observation, ${ }^{95}$ less than half of the graduates of Chinese secondary schools went to China, a few went to Taiwan and Western countries, and the rest remained in Indonesia working in private firms. The majority of students who went to China and Taiwan did not return, since the former were denied re-entry permits on their departure from Indonesia, 96 while the latter were not allowed to return because Indonesia had no diplomatic relations with Taiwan.

The Rise and Fall of Chinese-Medium Schools

The Indonesian government began to exercise more rigid control over Chinese-medium schools in 1957, at about the time of the outbreak of the regional protest movement in Indonesia. In March that year a state of war was declared and martial law imposed. The authorities claimed that firm control over Chinese schools had to be exercised to safeguard Indonesian national interests. On November 6, 1957 , a regulation was promulgated by Djuanda, in his capacity as Minister of Defense, which stipulated that Indonesian citizens were prohibited from entering alien (read: Chinese) schools. Furthermore, teachers in Chinese-medium schools and the schools themselves were required to obtain new permits from the Ministry of Education. New

pro-Taipei schools used textbooks published in Taiwan or by rightist publishing companies in Hong Kong. Especially at secondary school levels, it was believed by many Chinese parents in Djakarta that the pro-Peking schools provided their children with a better education in terms of science and other such courses, for the reason that they were we11-established. The Pa-chung, for instance, even had a few students whose parents were KMT leaders!

95. The author was educated in one of the secondary Chinese schools in Djakarta during 1955-1958. Although no figures are available on the Indonesian Chinese who either went to China and Taiwan or stayed in Indonesia, there are indications that more students went to China than to Taiwan. In 1956, there were about 33,000 overseas Chinese students in China (the proportion of students from Indonesia is unknown but it was undoubtedly significant); and on $1 y$ about 5,172 in Taiwan $(60$ in 1951,280 in 1952,632 in $1953,1,200$ in 1954. Figures for 1955 and 1956 are not available; I estimate that there were about 1,500 each year), of which probably one-fourth were from Indonesia (since in 1961 Indonesian Chinese students constituted about 20 per cent of the total overseas Chinese students in Taiwan). See China Yearbook 1962-63 (Taipei: China Publishing Co., n.d.), p. 305; China Yearbook 196465 (Taipei: China Publishing Co., n.d.), p. 603; Chou Sheng-kao, "Erh-shih nien lai te ch'iao-sheng chiao yü [Overseas Chinese Education (in Taiwan) in the Last Twenty Years]," Hsin shih-tai (Taipei), 12, no. 1 (January 1972), p. 16 .

96. It was a public secret that most Chinese students who went to China were barred from returning to Indonesia. See also Skinner, "The Chinese of Java," p. 8. 
schools were not allowed to be established. All textbooks used in Chinese-medium schools had to be approved by the Minister of Education. On November 20 , the Minister of Education promulgated a supplement to this regulation which reiterated the abovementioned points and outlined how they were to be implemented.97

The regulation of 1957 had a great impact on the Chinese communities in Indonesia. By drastically reducing the number of Chinese schools and introducing far stricter supervision over them, it worked to prevent peranakan Chinese children from being resinified through Chinese-medium schools and to separate them from their totok contemporaries.

The scale of the change can be judged from the fact that as of November 1957 , there were 2,000 Chinese-medium schools throughout Indonesia with 425,000 students, of whom 250,000 were Indonesian citizens; by July 1958 , there were only 850 Chinese-medium schools left, whose 150,000 students were all alien Chinese. (These schools were located in places determined by the Ministry of Education.) At the same time 1,100 Chinese-medium schools had been converted into Indonesian national schools. 98

The Badan Permusjawaratan Kewarganegaraan Indonesia (Baperki) or Indonesian Citizens' Consultative Body, a socio-political organization formed in March 1954 and aimed at protecting Indonesian citizens of Chinese origin, took over the management of the newly converted Indonesian-medium schools. These schools had the same curriculum as government schools except that the students were ethnic Chinese and Chinese was allowed to be taught as a subject. By this time, there were Chinese children studying in three different kinds of Indonesian-medium schools, i.e., government schools, schools run by missionaries, and Baperki schools. The number of Chinese attending these Indonesian-medium schools, unfortunately, is not available. However, taking into account the number of peranakan who were already studying in Indonesian-medium schools before 1957 , plus those who were affected by the 1957 regulation and were forced to go to Indonesian schools, I believe that more Chinese students were enrolled in Indonesian-medium schools than in Chinese-medium schools.

The number of Chinese-medium schools was still further reduced after October 1958 as a result of the 1958 regional rebellions. It was widely reported that weapons used by the rebels came from Taiwan through Singapore, while Taiwan newspapers bluntly defended the rebel1ions. The Indonesian government responded by asserting that proTaipei Chinese were involved in subversive activities. General Nasution, the Chief of Staff of the Indonesian Army, issued a regulation on October 16, 1958 prohibiting the operation of Chinese-medium schools associated with or owned by an alien country with no diplomatic relations with Indonesia (read: Taiwan). ${ }_{99}$ Almost half of the Chinese-medium schools (those affiliated with pro-Taipei groups) were then closed and taken over by the Indonesian authorities.

97. Departemen PP\&K, Pengawasan, pp. 70-75.

98. Ibid., p. 38 .

99. Ibid., pp. 116-119, 123-130 . 
From 1958 to 1965, in fact, the surviving Chinese-medium schools were mostly pro-Peking schools. These schools were under rigid supervision by the Ministry of Education. The teachers had to take tests, including an Indonesian language proficiency test, sponsored by the Ministry and only those who passed the tests were permitted to teach. The curriculum of these schools was also changed to include more subjects on Indonesia. Indonesian language, history and geography were prescribed as compulsory subjects, both at the primary and secondary levels. However, these subjects could be taught in either Indonesian or Chinese.

What were the prospects of further education for Chinese-medium secondary school graduates in this period? A small number continued to go to Taiwan for advanced education. ${ }^{100}$ A somewhat greater number went to China, but apparently fewer than in the 1950-1957 period. ${ }^{101}$ This was primarily due to a new Peking policy towards the overseas Chinese after 1957; henceforward, such Chinese were encouraged to integrate themselves with the local countries. ${ }^{102}$ In addition, many overseas Chinese students could not adjust themselves to the situation in China, a significant number leaving for Hong Kong and Macao, and others even illegally re-entering Indonesia. ${ }^{103}$ Discouragement from Peking combined with the difficulty that the Indonesian Chinese students had in adjusting to life in China deterred many secondary school graduates from going to China. The majority thus continued to stay in Indonesia and were absorbed into the private sector. (To deal with this situation, Chinese-medium schools were forced to review their curriculum.) Some graduates from Chinese-medium schools aspired to tertiary education in Indonesia, but most Indonesian universities were closed to them, the main exception being the

100. A total of 1,894 Indonesian Chinese students were in Taiwan by 1961. China Yearbook 1962-63 (Taipei: China Pub1ishing Co., n.d.), p. 305 .

101. Having no access to sources published in Peking, I have had to use Taipei's publications as my main reference. There were an average of 4,700 overseas Chinese studying in China annually prior to 1956 , but from 1957 onward, the number dropped to 1,400 a year. China Yearbook 1964-65 (Taipei: China Publishing Co., n.d.), p. 603. No information is available as to Indonesian Chinese students, but undoubtedly they formed a major component of the overseas Chinese student contingent.

102. For a study of the change in Peking's policy, see Stephen Fitzgerald, "China and the Overseas Chinese: Perceptions and Policies," The China Quarterly, 44 (October-December 1970), pp. 1-37.

103. It was reported that early in 1964 , more than 1,200 overseas Chinese students reached Hong Kong from China and refused to return. China Yearbook 1964-65, p. 603. I discovered (in 1966) that in both Hong Kong and Macao there were noticeable Indonesian Chinese communities consisting of former students from China. It was a public secret that other students from China were illegally re-entering Indonesia. There were many reports to this effect in the Indonesian press. For a rather recent example, see Yin-tu-ni-hsi-ya jih-pao (Chinese daily in Djakarta), June 13, 1968. 
Universitas Res Publica (Ureca), an Indonesian-medium university established by Baperki in the early sixties.

\section{Education for the Chinese After the 1965 Coup}

In October 1965 the greatest upheaval in modern Indonesian history took place. As a result, the Indonesian Communist Party (PKI) and other left-wing organizations, including Baperki, were banned. The Indonesian authorities accused Peking of supporting the PKI and being involved in the abortive coup. This time, all alien Chinese organizations affiliated with Peking were declared illegal; shortly afterward, a11 Chinese-medium schools were closed. As for the Baperki schools, including the Baperki-sponsored Ureca, they too were put under government supervision and eventually taken over by the authorities.

Alien Chinese children were deprived of any education for almost three years. Only early in 1968 did the Indonesian government issue a regulation, known as Presidential Regulation No. B12/Pres./I/1968, permitting the establishment of schools sponsored by private groups within the Chinese communities. These schools, called Sekolah Nasional Project Chusus (SNPC) or "Specia1 Project National Schools," came into being in 1969.104 They were declared open to aliens as we 11 as to Indonesian citizens, but the students have been mostly aliens. The curriculum follows that of regular government schools, its "specialness" lying only in the inclusion of the teaching of Chinese as a subject. At the present time, there are eight "specia1 Project National Schools" in Indonesia, five in Djakarta, two in palembang and one in Bandung. ${ }^{105}$ These schools are increasing in numbers since they are the only ones to which alien Chinese easily can be admitted. Nonetheless, the number is far too small to accommodate the bulk of alien Chinese children. (There are still about one million Chinese who are not Indonesian citizens.)

\section{Conclusion}

This historical survey shows that the Indonesian Chinese have consisted of groups with different interests reflected in their

104. For the full text of the regulation, see Lie Tek Tjeng, Masalah WNI dan Masalah Hoakiau di Indonesia (Djakarta: LIPI, 1970), pp. 60-61. For a study of the SNPC schools in Djakarta, see Mely G. Tan and Leo Suryadinata, "The 'Special Project National Schools' in Djakarta," a paper presented to the twenty-third Orientalists' Congress in Canberra, January 1971.

105. Based on information as of early 1971. These schools are the SNPC Bhinneka Tunggal Ika (Djakarta), the SNPC Djaja Sakti (Djakarta), the SNPC Sentosa (Djakarta), the SNPC Eka Dharma (Djakarta), the SNPC Samson (Djakarta), the SNPC Sumse1 Djaja (Palembang), the SNPC Sentosa tjabang Palembang (Palembang), and the SNPC Bina Budaja (Bandung). See Yin-tu-ni-hsi-ya jih-pao, February 12, 1969; June 6 and November 17, 18 and 23, 1970; January 20 and 25 , and February 10, 1971 . 
educational preferences. Peranakan Chinese, due to their peculiar cultural background and 1 ife in Indonesia, have usually preferred an education which is locally oriented; totok Chinese, on the other hand, have had strong cultural and perhaps family ties with China and have therefore been more attracted to Chinese education.

When the Chinese nationalist movement first flourished and the THHK schools were established to meet the demand of the Indies Chinese for modern education, the majority of the Chinese, peranakan and totok, sent their children to THHK schools. However, when the Dutch government responded to the challenge of the Chinese movement and provided peranakan Chinese with opportunities for a Dutch education, more and more peranakan shifted to Dutch schools. Not surprisingly, the Dutch schools, both government and private, increased spectacularly. Chinese-medium schools then fell into totok hands. Some peranakan Chinese were "totokized" through their Chinese education, but most remained peranakan.

The Japanese occupation gave another opportunity for peranakan Chinese to be "totokized," since many peranakan felt they had no choice but to send their children to Chinese-medium schools. This resulted in a considerable amount of resinification. But this resinification process did not persist because most peranakan Chinese continued to live in Indonesia where socio-political conditions did not favor the Chinese-educated. Chinese-medium schools became less and less attractive to most peranakan. Even some totok Chinese, seeing no prospects for Chinese education in Indonesia, began to send their children to non-Chinese medium schools. Especially after 1957, Indonesian citizens of Chinese descent, including both peranakan and totok, were increasingly forced to send their children to Indonesian-medium schools. One can thus argue that many younger generation totok who continue to live in Indonesia are being steadily "peranakanized." This development is certain to have accelerated since the closing of a11 Chinese-medium schools in 1966. 